\title{
OPERATIONS IN ISO 9001:2015
}

\author{
Radosław WOLNIAK \\ Silesian University of Technology, Department of Organization and Management, Institute of Economy and \\ Informatics; rwolniak@polsl.pl, ORCID: 0000-0003-0317-9811
}

Purpose: The aim of the paper is to analyse the problems connected with operations realised within an organisation in the ISO 9001:2015 implementation process.

Design/methodology/approach: Critical literature analysis. Analysis of international literature from main databases and Polish literature and legal acts connected with the researched topic.

Findings: The most important first part of the building operation system in the company is build this system according to ISO 9001:2015 requirements. An organisation, in this case, should plan, implement and control the processes needed to meet the requirements for the provision of products and services. The organisation need to ensure that outputs that do not conform to their requirements are identified and controlled to prevent their unintended use or delivery. The whole organisation should take appropriate actions based on the nature of the nonconformity and its effect on the conformity of products and services.

Originality/value: Detailed analysis of all subjects related to organisation of operations under the ISO 9001:2015 standard.

Keywords: quality management, ISO 9001:2015, ISO 9001, operations, product management, service management.

Category of the paper: literature review.

\section{Introduction}

The first part of the building operation system in the company according to ISO 9001:2015 requirements is operational planning and control (Kaoru, 1988; Pokińska et al., 2002; Robins and Coulter, 2006; Szkiel, 2016). An organisation, in this case, should plan, implement and control the processes needed to meet the requirements for the provision of products and services (ISO 9001:2015, Chen et al., 2016; Cholewicka-Goździk, 2016; Łagowski and Żuchowski, 2016; Wolniak, and Hąbek, 2015; Wolniak and Skonicka-Zasadzień, 2010; Wolniak and Sułkowski, 2015; Wolniak, 2020): 
- determining the requirements for the products and services;

- establishing criteria for:

- the processes,

- the acceptance of products and services;

- determining the resources needed to achieve conformity to the product and service requirements;

- implementing control of the processes in accordance with the criteria;

- determining and keeping documented information to the extent necessary:

- to have confidence that the processes have been carried out as planned,

- to demonstrate the conformity of products and services to their requirements.

The aim of the paper is to analyse the problems connected with operations realised within an organization in the ISO 9001:2015 implementation process.

\section{Basic concepts}

Quality planning requires a type of blueprint or guideline for an organisation that states how quality requirements are to be achieved (Hillson, 2001). The quality plan should have methodical approach or structure that describes and specifies all the requirements needed to be followed. Also it should to met, maintain and document realisation of the product and consist of all necessary information that would be usefull in manufacturing a product that meets requirements (Gębczyńska and Wolniak, 2018; Juszczak-Wiśniewska and Ligarski, 2015, 2016; Łuczak and Wolniak, 2016; Sułkowski and Wolniak, 2016, 2018; Szczucka-Lasota and Wolniak, 2018). The quality plan integrates all relevant demands for activities, resources and information concerning the realisation of a product and makes them available to interested parties (Horodecka and Wolniak, 2015; Pacana, 2014; Pacana et al., 2014, 2017; Pacana and Stadnicka, 2006, 2017; Wolniak, 2011; Wolniak and Sułkowski, 2015, 2016; Wolniak et al., 2019; Wolniak and Skotnicka-Zasadzień, 2008, 2011, 2019). The goals of the quality plan include the following (Abuhav, 2017; Hoyle, 2009; Ząbek, 2016; Żemigła, 2017):

- Identifying all the specifications and characteristics of a product, including quality requirements. These must match with the expectations of the customers.

- Identifying all the required processes and their activities needed for product realisation.

- Describing the necessary or expected inputs and outputs of each activity and so defining the relations between the various processes.

- Defining the required resources and conditions needed to support these activities. 
- Defining the controls that will ensure intended outcomes - validation and verification.

- Defining the criteria for acceptance (or rejection) of outputs of activities (processes or products).

The following types of documented information may be used or referred to by the quality planning (Abuhav, 2017; Salvendy, 2001):

- Customer specifications.

- Drawings.

- Standards and regulations.

- Process diagrams.

- Instructions, such as work instruction.

- Test protocols.

\section{Operation planning and control}

Product specific processes are required for the provision of products. The scheme of operation planning and the control process is presented in Figure 1. Operational planning and control require that product-specific processes should be planned, implemented and controlled for (Natarjan, 2017; Wolniak, 2013, 2014, 2016, 2017, 2019; Wolniak and Sktnicka-Zasadzień, 2014):

- meeting product conformity and delivery requirements for the provision of products;

- implementing the actions determined to address risks and opportunities for the processes.

In process planning, a decision regarding the acceptance or rejection of a process, an activity or an outcome should be made (Ścierski, 2011), and this should have the instructional roles and guidelines that allow personnel to make a judgment regarding process outputs, which include the following (Abuhav, 2017):

- Compliance with applicable standards.

- Compliance with applicable regulations.

- Compliance with quality objective.

- Compliance with intended outputs.

- Compliance with product specifications. 


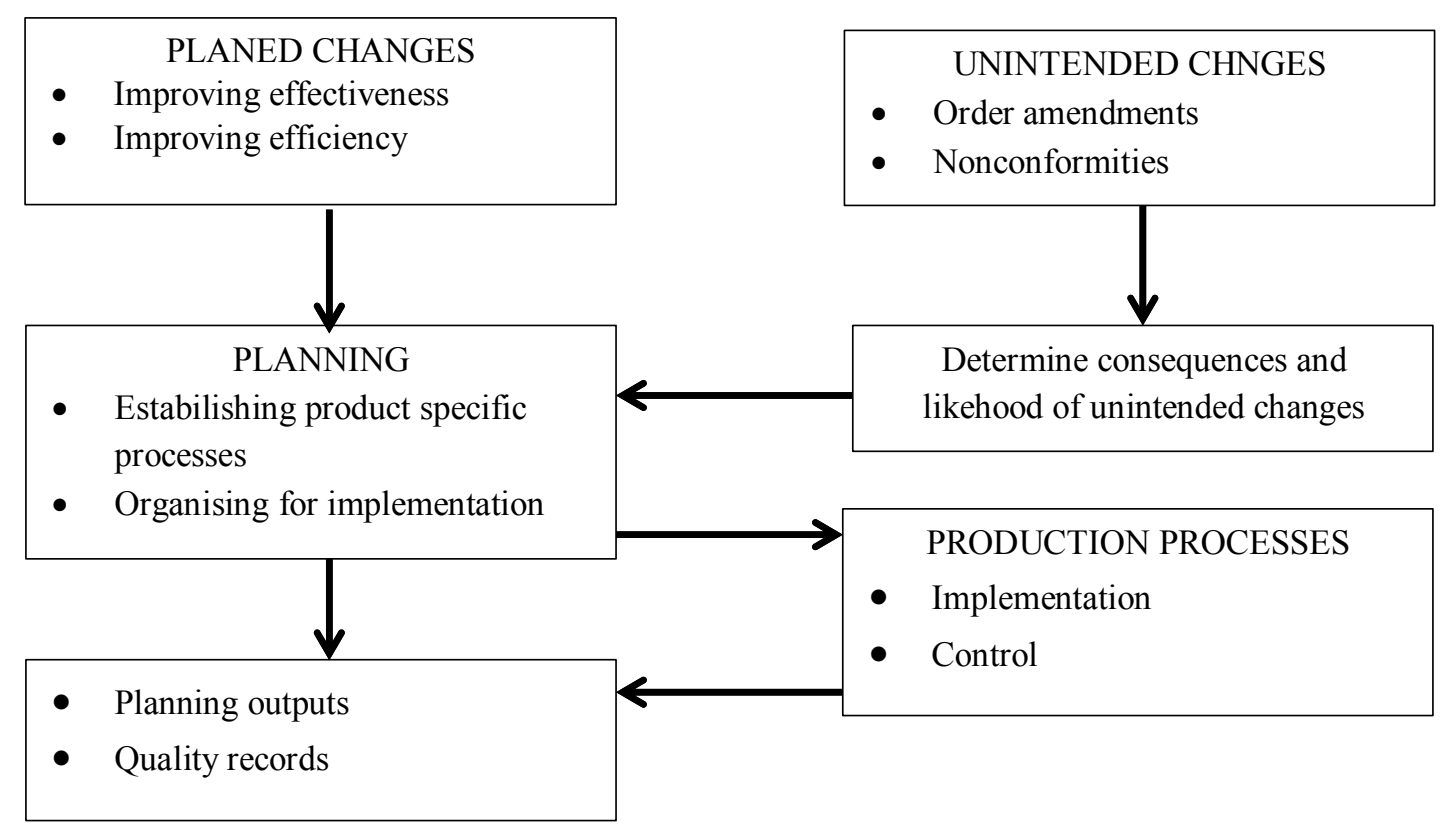

Figure 1. Operation planning and control. Source: (Natarjan, 2017).

Organising for the implementation of product processes to provide products that meet customer requirements is needs changing many activity in operational planning area. Planning for the implementation and control of production processes requires (Natarjan, 2017; Ligarski, 2013, 2014; Stramatis, 1995):

- interacting with marketing for the requirements for products;

- interacting with design and development for new products;

- verifying the status of in-house stock levels and work-in-progress with internal processes and external providers;

- organising and controlling externally provided processes and products;

- organising and controlling internal production processes;

- processing the property belonging to customers for production processes.

If one of the quality objectives is to reduce customers complaints and an analysis of the identified complaints show that a specific product characteristic generates the problem and the complaints, organisations should define the following criteria for this characteristic (Abuhav, 2017; Locher, 2008):

- Criteria for acceptance or rejection of process outputs - criteria that would ensure that process outputs achieve their objectives.

- Criteria for acceptance or rejection of final product - criteria that would ensure that all product requirements are realised, for example, test protocols or test instructions.

- Criteria for quality of special processes - criteria for validation and approval of processes where the resulting output cannot be verified by subsequent monitoring or measurement. 
- Criteria for customer satisfaction - criteria that will be used to evaluate the degree of customer satisfaction.

- Criteria for the evaluation of performance of external providers (suppliers or subcontractors) - criteria related to performance of suppliers.

- Criteria for the release of products or services - criteria that will be used to decide whether the product meets all its requirements.

- Criteria needed to evaluate changes in processes or product requirements - criteria necessary to ensure that all conditions for the release of changes in process or product are defined and to evaluate the consequences of the change.

- Criteria for process environment - criteria necessary for approval that environmental work conditions that may affect processes or products were maintained.

- Criteria for the handling of nonconformed products - criteria that should assist in deciding what is to be done with nonconformed products: approval for use, disposal, segregation or rework.

\section{Requirements}

Organisations should ensure that they have the ability to meet the requirements for products and services to be offered to customers. The aims of the organisations that should be fulfilled in the case of requirements for products and services are presented in Table 1. Organisations need to conduct a review before committing to supply products and services to customers and should ensure that any contract or order requirements differing from those previously defined are resolved (Mitra, 2016; Montgomery, 2009). The customer's requirements should be confirmed by the organisation before acceptance or when a customer does not provide a documented statement of their requirements. If applicable, the organisation should retain documented information (ISO 9001:2015):

- on the results of the review;

- on any new requirements for the products and services.

Table 1.

Requirements for products and services in ISO 9001:2015

\begin{tabular}{|c|c|}
\hline Requirement & Characteristic \\
\hline $\begin{array}{c}\text { Customer } \\
\text { communication }\end{array}$ & $\begin{array}{l}\text { - } \quad \text { providing information relating to products and services; } \\
\text { - } \quad \text { handling enquiries, contracts or orders, including changes; } \\
\text { - } \text { obtaining customer feedback relating to products and services, including } \\
\text { customer complaints; } \\
\text { - } \quad \text { handling or controlling customer property; } \\
\text { - establishing specific requirements for contingency actions, when relevant. }\end{array}$ \\
\hline
\end{tabular}


Cont. table 1.

\begin{tabular}{|c|c|}
\hline $\begin{array}{l}\text { Determining the } \\
\text { requirements related } \\
\text { to products and } \\
\text { services }\end{array}$ & $\begin{array}{l}\text { - the requirements for the products and services are defined, including: } \\
\circ \text { any applicable statutory and regulatory requirements, } \\
\circ \quad \text { those considered necessary by the organisation; } \\
\text { - the organisation can meet the claims for the products and services it offers. }\end{array}$ \\
\hline $\begin{array}{l}\text { Review of } \\
\text { requirements }\end{array}$ & $\begin{array}{l}\text { - requirements specified by the customer, including the requirements for delivery } \\
\text { and postdelivery activities; } \\
\text { - requirements not stated by the customer, but necessary for the specified or } \\
\text { intended use, when known; } \\
\text { - requirements specified by the organisation; } \\
\text { - } \quad \text { statutory and regulatory requirements applicable to the products and services; } \\
\text { contract or order requirements differing from those previously expressed. }\end{array}$ \\
\hline $\begin{array}{l}\text { Changes to } \\
\text { requirements }\end{array}$ & $\begin{array}{l}\text { The organisation shall ensure that relevant documented information is amended, } \\
\text { and that relevant persons are made aware of the changed requirements, when the } \\
\text { requirements for products and services are changed. }\end{array}$ \\
\hline
\end{tabular}

Source: Own work on the basis of (ISO 9001:2015).

In order to be successful in any business, it is necessary to clearly understand the requirements of the customer. The organisation needs to take the initiative when determining the customer's needs and not expect the customer to explain everything (Purushothama, 2015).

The information regarding products or services may include attributes such as (Abuhav, 2017; Novakova et al., 2016):

- The description of the product.

- The usage of the goods or service.

- Training necessary for the use of the product.

- Instructions or warnings regarding the use and operation of the product.

- Previous editions or versions of the product.

- Materials, components and characteristics of the product.

- Processes and realisation activities of the product.

- Warnings and advisory notices regarding the product.

- Changes, updates and improvements in the product.

Communication with customer also includes the following points (Natarajan, 2015; Olkiewicz et al., 2019):

- Providing information relating to products: Customers require product-related information for various applications, and organisations should provide the information. Some forms of providing information are product catalogues and application notes for products. Free samples could be provided for the developmental projects of customers.

- Handling enquiries, contracts or orders, including changes: The requirements for products are communicated by customers to organisations in many ways. Enquiries might be verbal or in written form. Customers might release repeat orders directly without formal enquiries based on previous quotations. The organisation processes enquiries, contracts or orders and changes from customers and sends quotations and the order acceptance to customers accordingly. 
- Customer feedback and complaints relating to products: The organisation maintains documented information for obtaining customer feedback relating to products. Obtaining customer feedback is part of the quality procedure for customer satisfaction.

- Handling or controlling customer property: Customer property, when received, is identified. The information and the customer's property are sent to the process owner of operational planning for organising inspection, preservation and use.

- Establishing specific arrangements for contingency actions: When relevant, specific arrangements for contingency actions are established. For example, an elite customers might require products with a short delivery period. The customer enquiry warrants establishing specific arrangements for contingency actions before committing to the supply of the products.

An extended analysis of customer needs should concentrate on (Purushothama, 2015):

- Requirements for the goods and services, taking into consideration relevant quality objectives: The purpose for which the product or service is being produced should be clear to all involved in the organisation. By considering the objectives of the products and services, the requirements of raw materials, machines, settings, men, etc. need to be decided.

- Actions to identify and address risks related to achieving the conformity of goods and services to requirements: Before starting an activity, it is necessary to address the risks or problems likely to be faced and devise preventive measures to overcome these problems. This is similar to providing safety gadgets and safety systems for preventing accidents. The risks may be unfavourable climatic conditions, absenteeism of skilled employees, shortage of certain components, raw material quality not being up to spec, poor machinery conditions, etc.

- The resources that will be required arising from the requirements for the goods and services: The specific resources required for the products and services are to be identified and procured in time.

- The criteria for the acceptance of goods and services: The criteria for the acceptance of goods and services are to be as per the customer's requirements and not as per some standards suggested by the research organisation or standards bodies.

- Required verification, validation, monitoring, measurement, inspection and test activities specific to the goods and services: Depending on the product objectives, the activities of verification, validation, monitoring, measurement and inspection and test activities need to be designed.

- How the performance data will be established and communicated depends on the criticality of the product.

- Requirements for traceability, preservation, goods and services, delivery and postdelivery activities are to be decided according to the number of products and types of products being manufactured. Even if the entire organisation produces only one variety, then a suitable colour codification should also to be incorporated to identify the lots. 
In the next stage, organisations should establish, implement and maintain a design and development process that is appropriate to ensure the subsequent provision of products and services. The requirements for the products and services may be influenced by several important factors (Abuhav, 2017):

- Requirements that are defined in a contract.

- Results of market research.

- Known needs and expectations of the customer.

- Requirements provided by the customer, for example, as a request for purchasing or a tender.

- Necessary requirements of the organisation, such as quality requirements or regulatory requirements.

- New requirements that are the results of a change in customer expectations.

\section{Conclusion}

An organisation need to ensure that outputs that do not conform to their requirements are identified and controlled to prevent their unintended use or delivery. The entire organisation should take appropriate actions based on the nature of the nonconformity and its effect on the conformity of products and services. This should also apply to nonconforming products and services detected after delivery of the products, as well as during or after the provision of services. Organisations need to deal with nonconforming outputs in one or more of the following ways (Abuhav, 2017):

- Correction.

- Segregation, containment, return or suspension of provision of products and services.

- Informing the customer.

- Obtaining authorisation for acceptance under concession.

The organisation should also verify the conformity to requirements when nonconforming outputs are corrected. It shall retain documented information that:

- describes the nonconformity;

- describes the actions taken;

- describes any concessions obtained;

- identifies the authority deciding the action in respect of the nonconformity. 


\section{References}

1. Abuhav, I. (2017). ISO 9001:2015. A Complete Guide to Quality Management Systems, London: CRC Press.

2. Chen, C.K., Lee, J.D., Dahlgaard, J.J. (2016). A stepwise ISO-based TQM implementation approach using ISO 9001:2015, Management and Production Engineering Review, 4, 65-75.

3. Cholewicka-Goździk, K. (2016). Struktura normy ISO 9001:2015, podstawowe wymagania, Problemy Jakości, 1, 25-30.

4. Gębczyńska, A., Wolniak, R. (2018). Process management level in local governemnt, Philadelphia: CreativeSpace.

5. Hillson, D. (2001). Effective strategies for exploiting opportunities, Nashville: Tennessee.

6. Horodecka, A.M., Wolniak, R. (2015). Valutazione delle non conformita nell'esempio di un Azienda Italiana. In: J. Kaźmierczak (ed.), Systemy Wspomagania Inżynierii Produkcji. Review of problems and solutions, 18-31.

7. Hoyle, D. (2009). ISO 9000. Quality systems handbook, Boston: Elsevier.

8. ISO 9001:2015. Quality management systems - Requirements.

9. Juszczak-Wiśniewska, A., Ligarski, M. (2015). Weryfikacja przydatności opracowanego narzędzia badawczego do analizy problemów w systemach zarządzania jakością, Zeszyty Naukowe Politechniki Ślaskiej. Seria Organizacji i Zarządzanie, 80, 133-141.

10. Juszczak-Wiśniewska, A., Ligarski, M. (2015). Analysis of the causes the quantitative changes and trends in conferred ISO 9001 certificates in Poland Research based on the data from audits, Systemy Wspomagania w Inżynierii Produkcji, 1, 42-50.

11. Juszczak-Wiśniewska, A., Ligarski, M. (2016). Akredytacja i certyfikacja systemów zarządzania jakością w placówkach medycznych w Polsce - wyniki badań, Systemy Wspomagania w Inżynierii Produkcji, 2, 163-171.

12. Kaoru, I. (1988). What is Total Quality Control? The Japanese Way, Prentice-Hall: Englewood Cliffs.

13. Łagowski, E., Żuchowski, J. (2016). Aktualizacje normy ISO $9001 \mathrm{w}$ aspekcie bieżących potrzeb gospodarczych, Problemy Jakości, 10, 15-22.

14. Ligarski, M. (2013). Problems examination in quality management system, Acta Technologica Agriculture, 4, 108-112.

15. Ligarski, M. (2014). Diagnoza systemu zarządzania jakością w polskich organizacjach, Problemy Jakości, 5, 14-22.

16. Locher, D. (2008). Value Stream Mapping for Lean Development, New York: Taylor \& Francis.

17. Łuczak, J., Wolniak, R. (2016). Integration of quality environment and safety management systems in a foundry, Metalurgija, 4, 843-845.

18. Mitra, A. (2016). Fundamentals of Quality Control improvement, New Jersey: Wiley \& Sons. 
19. Montgomery, D.C. (2009). Introduction to statistical quality control, New York: Wiley \& Sons.

20. Natarajan, D. (2017). ISO 9001. Quality Management Systems, Bangalore: Springer.

21. Novakova, R., Cekanova, K., Paulikova, A. (2016). Integration management system - new of requirements of ISO 9001:2015 and ISO 14001:2015 standards, Production Engineering Archives, 4, 35-40.

22. Olkiewicz, M., Wolniak, R., Grebski, E.M., Olkiewicz, A. (2019). Comparative analysis of the impact of the business incubator center on the economic sustainable development of regions in USA and Poland, Sustainability, 1, 1-22.

23. Pacana, A. (2014). Synteza i doskonalenie wdrażania systemów zarządzania jakościa zgodnych z ISO 9001 w małych i średnich organizacjach, Rzeszów: Oficyna Wydawnicza Politechniki Rzeszowskiej.

24. Pacana, A., Gazda, A., Bednárová, L. (2014). The impact of quality information on innovatory environment of the publlic administration, International Journal of Interdisciplinarity in Theory and Practice, 4, 25-26

25. Pacana, A., Ingaldi, M., Czajkowska, A. (2017). Projektowanie $i$ wdrażanie sformalizowanych systemów zarzązania, Rzeszów: Wydawnictwo Politechniki Rzeszowskiej.

26. Pacana, A., Lew, G., Kulpa, W. (2017). Rating the quality of implementation of environmental management systems. Journal of Business \& Retail Management Research, 11(2), 165-169

27. Pacana, A., Stadnicka, D. (2006). Wdrażanie i audytowanie systemów zarządzania jakościa zgodnych z norma ISO 9001:2000, Rzeszów, Oficyna Wydawnicza Politechniki Rzeszowskiej.

28. Pacana, A., Stadnicka, D. (2017). Nowoczesne systemy zarzadzania jakościa zgodne z ISO 9001:2015, Rzeszów, Wydawnictwo Politechniki Rzeszowskiej.

29. Poksińska, P., Dahlgaard, J.J., Marc, A. (2002). The state of ISO 9000 certification. A study of Swedish organizations, The TQM Magazine, 5, 297-305.

30. Purushothama, B. (2015). Implementing ISO 9001:2015, New Delhi: Woodhead Publishing India.

31. Robbins, S., Coulter, M. (2006). Management, New York: Prentice Hall.

32. Salvendy, G. (2001). Handbook of Industrial Engineering. Technology and operations Management, New York: John Wiley \& Sons.

33. Ścierski, J. (2011). Nowelizacja normy ISO 9001, Zeszyty Naukowe Politechniki Ślaskiej. Seria Organizacji i Zarzadzanie, 59, 101-117.

34. Stamatis, D.H. (1995). Understanding ISO 9000 and implementing the basics to Quality. New York: CRC Press.

35. Sułkowski, M., Wolniak, R. (2016). Przegląd stosowanych metod oceny skuteczności i efektywności organizacji zorientowanych na ciągłe doskonalenie, Zeszyty Naukowe Politechniki Ślaskiej. Seria Organizacja i Zarzadzanie, 67, 63-74. 
36. Sułkowski, M., Wolniak, R. (2018). Poziom wdrożenia instrumentów zarzadzania jakościa w przedsiębiorstwach branży obróbki metali, Częstochowa: Oficyna Wydawnicza Stowarzyszenia Menedżerów Produkcji i Jakości.

37. Szczucka-Lasota, B., Wolniak, R. (2018). Control plan and research supply as a tool in the process of decision making, Zeszyty Naukowe Politechniki Ślaskiej. Seria Organizacja i Zarzadzanie, 115, 439-447.

38. Szkiel, A. (2016). Orientacja na klienta w wymaganiach normy ISO 9001:2015, Marketing i Zarzadzanie, 3, 83-93.

39. Wolniak, R. (2011). Parametryzacja kryteriów oceny poziomu dojrzałości systemu zarządzania jakością, Gliwice: Wydawnictwo Politechniki Śląskiej.

40. Wolniak, R. (2013). A typology of organizational cultures in terms of improvement of the quality management, Manager, 17(1), 7-21.

41. Wolniak, R. (2013). Normalizacja zarządzania jakością a wymiary kulturowe kraju, Problemy Jakości, 9, 19-25.

42. Wolniak, R. (2013). Projakościowa typologia kultur organizacyjnych, Przeglad Organizacji, 3, 13-17.

43. Wolniak, R. (2013). W kierunku ISO 9001:2015, Problemy Jakości, 2, 10-14.

44. Wolniak, R. (2014). Korzyści doskonalenia systemów zarządzania jakością opartych o wymagania normy ISO 9001:2009, Problemy Jakości, 3, 20-25.

45. Wolniak, R. (2016). Kulturowe aspekty zarządzania jakością. Etyka biznesu i zrównoważony rozwój, Interdyscyplinarne studia teoretyczno-empiryczne, 1, 109-122.

46. Wolniak, R. (2016). Metoda QFD w zarządzaniu jakością. Teoria i praktyka, Gliwice: Wydawnictwo Politechniki Śląskiej.

47. Wolniak, R. (2017). Analiza relacji pomiędzy wskaźnikiem innowacyjności a nasyceniem kraju certyfikatami ISO 9001, ISO 14001 oraz ISO/TS 16949. Kwartalnik Organizacja i Kierowanie, 2, 139-150.

48. Wolniak, R. (2017). Analiza wskaźników nasycenia certyfikatami ISO 9001, ISO 14001 oraz ISO/TS 16949 oraz zależności pomiędzy nimi, Zeszyty Naukowe Politechniki Ślaskiej. Seria Organizacji i Zarządzanie, 108, 421-430.

49. Wolniak, R. (2017). The Design Thinking method and its stages, Systemy Wspomagania Inżynierii Produkcji, 6, 247-255.

50. Wolniak, R. (2017). The use of constraint teory to improve organization of work, 4th International Multidisciplinary Scientific Conference on Social Sciences and Arts. SGEM 2017, 24-30 August 2017, Albena, Bulgaria. Conference proceedings. Book 1, Modern science. Vol. 5, Business and management. Sofia: STEF92 Technology, 1093-1100.

51. Wolniak, R. (2019). Context of the organization in ISO 9001:2015, Silesian University of Technology Scientific Papers. Organization and Management Series, 133, 121-136.

52. Wolniak, R. (2019). Downtime in the automotive industry production process - cause analysis, Quality, Innovation, Prosperity, 2, 101-118. 
53. Wolniak, R. (2019). Leadership in ISO 9001:2015, Silesian University of Technology Scientific Papers. Organization and Management Series, 133, 137-150.

54. Wolniak, R. (2019). Support in ISO 9001:2015, Silesian University of Technology Scientific Papers. Organization and Management Series, 137, 247-261.

55. Wolniak, R. (2019). The level of maturity of quality management systems in Poland-results of empirical research, Sustainability, 15, 1-17.

56. Wolniak, R. (2020). Quantitative relations between the implementation of industry management systems in European Union countries, Silesian University of Technology Scientific Papers. Organization and Management Series, 142, 33-44.

57. Wolniak, R., Grebski, M.E., Skotnicka-Zasadzień, B. (2019). Comparative analysis of the level of satisfaction with the services received at the business incubators (Hazleton, PA, USA and Gliwice, Poland), Sustainability, 10, 1-22.

58. Wolniak, R., Hąbek, P. (2015). Quality management and corporate social responsibility. Systemy Wspomagania w Inżynierii Produkcji, 1, 139-149.

59. Wolniak, R., Skotnicka, B. (2011).: Metody i narzędzia zarządzania jakościa - Teoria i praktyka, cz. 1, Gliwice: Wydawnictwo Naukowe Politechniki Śląskiej.

60. Wolniak, R., Skotnicka-Zasadzień, B. (2008). Wybrane metody badania satysfakcji klienta i oceny dostawców w organizacjach, Gliwice: Wydawnictwo Politechniki Śląskiej.

61. Wolniak, R., Skotnicka-Zasadzień, B. (2010). Zarządzanie jakościa dla inżynierów, Gliwice: Wydawnictwo Politechniki Śląskiej.

62. Wolniak, R., Skotnicka-Zasadzień, B. (2014). The use of value stream mapping to introduction of organizational innovation in industry, Metalurgija, 53(4), 709-713.

63. Wolniak, R., Skotnicka-Zasadzień, B., Zasadzień, M. (2019). Problems of the functioning of e-administration in the Silesian region of Poland from the perspective of a person with disabilities, Transylvanian Review of Public Administration, 57E, 137-155.

64. Wolniak, R., Sułkowski, M. (2015). Motywy wdrażanie certyfikowanych Systemów Zarządzania Jakością. Problemy Jakości, 9, 4-9.

65. Wolniak, R., Sułkowski, M. (2015). Rozpowszechnienie stosowania Systemów Zarządzania Jakością w Europie na świecie - lata 2010-2012, Problemy Jakości, 5, 29-34.

66. Wolniak, R., Sułkowski, M. (2016). The reasons for the implementation of quality management systems in organizations, Zeszyty Naukowe Politechniki Śląskiej. Seria Organizacji i Zarządzanie, 92, 443-455.

67. Ząbek, J. (2016). ISO 9001:2015. Wybrane problemy zarządzania z perspektywy nowej normy, Ekonomika i Organizacja Przedsiębiorstwa, 2, 14-25.

68. Żemigała, M. (2017). Tendencje w badaniach nad normą ISO 9001. Problemy Jakości, 3, 2-9. 